\title{
Alcohol use disorder and associated factors among individuals living with HIV in Hawassa City, Ethiopia: a facility based cross- sectional study
}

\author{
Bereket Duko $^{1 *}$ (D) Alemayehu Toma ${ }^{2}$ and Yacob Abraham ${ }^{1}$
}

\begin{abstract}
Background: Individuals living with HIV/AIDS with co-occurring harmful alcohol use may require specialized intervention or even multi-disciplinary team follow-up and management. This study was aimed to assess alcohol use disorder and associated factors among people living with HIV/AIDS in Hawassa city, Ethiopia, 2019.

Methods: A facility based cross-sectional study was conducted among 195 people living with HIV/AIDS who had follow-up visit at Hawassa University Comprehensive Specialized hospital. A systematic sampling technique was used to recruit the study participants. Alcohol used disorders identification test (AUDIT) was used to measure alcohol consumption, drinking behaviors, and alcohol-related problems. The binary logistic regression model was used to see the association between alcohol use disorder (AUD) and the independent variables. The strength of association was measured by odds ratios with 95\% confidence intervals. Statistical significance declared at $P<0.05$.

Results: The mean age of the study participants was $29.88( \pm S D=10.89)$ years. The magnitude of alcohol use disorder among people living with HIV/AIDS was 31.8\%. Being male [AOR $=2.43$, (95\% Cl: 1.76, 5.76)], having poor social support $[A O R=1.34,(95 \% \mathrm{Cl}: 1.12,6.73)]$, being medication non-adherent $[\mathrm{AOR}=1.78,(95 \% \mathrm{Cl}: 1.33,6.79)]$, current khat chewing $[A O R=1.67,(95 \% \mathrm{Cl}: 1.16,5.45)]$ and current cigarette smoking $[\mathrm{AOR}=3.76,(95 \% \mathrm{Cl}: 2.16,7$. 54)] had statistically significant association with alcohol use disorder.

Conclusion: In the current study, magnitude of alcohol use disorder among people living with HIV was high and, calls for integrating services provided to HIV patients in HIV care and treatment clinic which enhances timely detection and management of AUD cases. This also alerts the stakeholders in HIV prevention and control programs to invest a greater efforts to retain patients in addiction treatment and rehabilitation centers. Lastly, appropriate screening and health education on consequences of alcohol use disorder is warranted.
\end{abstract}

Keywords: Alcohol use disorder, Associated factors, HIV, AIDS, Ethiopia

\section{Background}

Alcohol use disorder increases hospitalization and have negative effects on the life expectancy of patients infected with the human immunodeficiency virus (HIV) [1]. Alcohol can aggravate immunosuppression, impair cognitive function, often have detectable viral levels, and alcohol consumption may reduce patient adherence to

\footnotetext{
* Correspondence: berkole.dad@gmail.com

${ }^{1}$ Faculty of Health Sciences, College of Medicine and Health Sciences,

Hawassa University, P. O. Box 1560, Hawassa, Ethiopia

Full list of author information is available at the end of the article
}

ART, which can lead to treatment failure and leads to drug resistance to antiretroviral [2-5]. Moreover, hazardous alcohol use increases sexual risk behaviors for unprotected sex practice that leads to disseminating drug exposed virus to the public [2-6].

Alcohol misuse is among in the group of problem in low-income countries including Ethiopia [7]. A study conducted on drug and alcohol abuse in Ethiopia revealed that the prevalence of hazardous alcohol use and alcohol dependence was 3 and $1.5 \%$ in general population respectively [8]. Different studies showed that

(C) The Author(s). 2019 Open Access This article is distributed under the terms of the Creative Commons Attribution 4.0 International License (http://creativecommons.org/licenses/by/4.0/), which permits unrestricted use, distribution, and 
higher prevalence of AUD among HIV patients; $32 \%$ in Ethiopia [9], 38.4\% in four African country [10], 42\% in Nepal [11], 39.4\% in Nigeria [12] and $74.3 \%$ in New York, USA [13].

The most significant cause of ART interruption especially among men is harmful or hazardous alcohol use $[5,6]$. The effectiveness of antiretroviral medication is highly dependent on patient adherence to highly active antiretroviral therapy (HAART) to significantly decrease HIV-related morbidity and mortality [3-5]. Being male sex, severe or moderate anxiety, being a college student, HIV related stigma and illicit drug use including tobacco are highly associated with alcohol use, and illicit drug use and CD4 count greater than or equal to 500 cells/microliter are highly associated with hazardous drug use [9-13].

Health care providers are more often missing alcohol use problems in patients with less severe HIV infection and those without evidence of chronic diseases including liver disease [6]. Using specific instruments for assessing alcohol consumption enables the identification of less evident cases of alcohol abuse in HIV screening [14-19]. Patients with HIV/AIDS with hazardous or harmful alcohol use may require specialized intervention or even multi-disciplinary team follow-up and management [14-22]. This alerts the stakeholders in HIV prevention and control programs to invest greater efforts to retain patients in addiction treatment and rehabilitation centers [20,21].

Early detection of alcohol use disorder in HIV infected patients may strengthen the effectiveness of the medication which is significant for poor therapeutic adherence [20-22]. There is limited data concerning alcohol use disorder in HIV infected patients in Ethiopia for tailored prevention, diagnosis and treatment care in local context. Therefore, this cross-sectional study was aimed to assess the magnitude of alcohol use disorder and associated factors among patients with HIV/AIDS in Ethiopia.

\section{Methods}

\section{Study design and setting}

A facility based cross-sectional study was carried out to assess the epidemiology of alcohol use disorder and associated factors among patients living with HIV at Hawassa University Comprehensive Specialized Hospital, Hawassa, Ethiopia. This hospital is the only comprehensive specialized hospital found in Hawassa city, Ethiopia, which is situated $273 \mathrm{~km}$ from Addis Ababa, Ethiopia. It delivers both outpatient and inpatient services for more than 18 million population with more than 400 beds. In average, the hospital provides services for people living with HIV/AIDS at the ART clinic for more than 50 patients/day.

\section{Sample size determination and sampling procedure} Single population proportion formula was used to get the required sample size using prevalence of AUD among HIV patients in Ethiopia, 14.2\% [23], with a 95\% confidence interval and 5\% of margin error. We used systematic sampling techniques to recruit the study participants through three intervals $(K=3)$. The first study participant among the 1st three participants selected through the lottery method. Among individuals who had a follow up visit at ART clinic, a total of 195 individuals with HIV who were with age of $\geq 18$ years were selected for the study. Two study participants excluded from the study due to their hearing problems and critical stage of their illness.

\section{Data collection instruments and procedures}

Four trained psychiatry nurses who had taken three days training on data collection had collected the data through an interviewer-administered questionnaire. Alcohol used disorders identification test (AUDIT) was used to measure alcohol consumption, drinking behaviors, and alcohol-related problems. It is a 10-items screening tool which was developed by WHO to identify alcohol use disorders for the last 12 months. The score of > eight or more in AUDIT was considered as alcohol use disorder. The scale has been validated in different ethnic groups and across genders with the sensitivity of $94.1 \%$ and specificity of $91.7 \%$, is well-suited for use in primary care settings [24]. It was translated into Amharic which was the main languages spoken in the study area and back-translated to English by English language experts. It was tested in our pretest and highly reliable in our study (Cronbach's alpha $=0.94$ ). Perceived HIV stigma scale was used to assess self-felt stigma by HIV patients. It is a Likert type of scale with four possible answers (strongly disagree $=1$, disagree $=2$, agree $=3$ and strongly agree $=4$ ) to questions or statements on their opinions and feeling concerning how persons behave towards due to their HIV illness [25, 26]. ART medication adherence was looked at using the Morisky Medication Adherence Scale which is validated for the measure of medication non-adherence in a variety of patient populations and with over 110 versions and over 80 translations [27]. The Oslo 3-items social support scale was used to estimate the level of social support of the study participant's percept. It is a scale with the sum score ranging from 3 to $14,3-8$ is" poor support", 9-11 is" moderate support" and 12-14 is" strong support". In this study, we consider good social support when the sum score is $\geq 9$. It has been used in many population-based studies in Ethiopia [28]. Perceived HIV stigma, Morisky Medication Adherence Scale and Oslo social support scale were also highly reliable in this study with Cronbach's alpha of $0.88,0.92$ and 0.94 respectively. 


\section{Data processing and analyses}

The checked and coded data was entered into Epi-Info version 7.0. Then transported to SPSS version 22 to analyze the data. Descriptive (frequency) statistics was done to get the distribution of socio-demographic, clinical and environmental factors and, a prevalence of AUD. The binary logistic regression model was used to see the association between AUD and the independent variables. Variables with a $P$-value of 0.20 and other variables of interest were entered into the multivariable logistic regression analysis. The strength of association was measured by odds ratios with 95\% confidence intervals. Statistical significance was declared at $P<0.05$.

\section{Results}

\section{Socio-demographic characteristics of the study} participants

A total of 195 individuals with HIV enrolled in the study with response rate of $98.9 \%$. The mean age of the study participants was $29.88( \pm \mathrm{SD}=10.89)$ years. Most of the study participants were in the age group of 35-44 years (40\%), married (55.4) and living with their family (74.4\%) (Table 1).

\section{Clinical and psychosocial characteristics of the study participants}

Among the respondents, 45.1 were with the illness duration of $5-10$ years, $55 \%$ had good social support and 24.6\% had TB/HIV coinfections (Table 2). Among the study participants who were classified as alcohol use disorder, $16.4 \%$ initiated drinking alcohol due to easily availability of alcohol, 13.8 and $11.8 \%$ started drinking alcohol due to peer pressure and lack of social support respectively (Table 3). Among those with AUD, 48.3\% were preferred factory bottled beer, $35.4 \%$ were preferred locally brewed beer ('tella' and teji) and $19.4 \%$ were preferred arake.

\section{Prevalence of alcohol use disorder and associated factors}

The prevalence alcohol use disorder among people living with HIV using AUDIT with cut-off point $\geq 8$ was $31.8 \%$. Finding from binary logistic regression analysis revealed that being male, having poor social support, current khat chewing, current cigarette smoking and poor medication adherence were statistically significant association with alcohol use disorder (Table 4).

\section{Discussion}

In this study, the prevalence of alcohol use disorder among individuals with HIV was $31.8 \%$ (CI: 25.133.4). The prevalence of this study was in-line with the other studies in Ethiopia which was 32.6\% [9], $30.7 \%$ in Togo [10], 25.7\% in Nepal [29], 28.6\% in
Table 1 Frequency for socio-demographic and socioeconomic characteristics of the study participants, Hawassa, Ethiopia, $2019(n=195)$

\begin{tabular}{|c|c|c|c|}
\hline Characteristics & Category & Frequency & Percent (\%) \\
\hline \multirow[t]{4}{*}{ Age } & $18-24$ years & 13 & 6.7 \\
\hline & $25-34$ years & 55 & 28.2 \\
\hline & $35-44$ years & 78 & 40.0 \\
\hline & $\geq 45$ years & 49 & 25.1 \\
\hline \multirow[t]{2}{*}{ Sex } & Male & 87 & 44.6 \\
\hline & Female & 108 & 55.4 \\
\hline \multirow[t]{4}{*}{ Religion } & Orthodox & 72 & 37.0 \\
\hline & Protestant & 81 & 41.5 \\
\hline & Muslim & 17 & 8.7 \\
\hline & Catholic & 25 & 12.8 \\
\hline \multirow[t]{4}{*}{ Marital status } & Unmarried & 39 & 20.0 \\
\hline & Married & 108 & 55.4 \\
\hline & Divorced & 32 & 16.4 \\
\hline & Widowed & 16 & 8.2 \\
\hline \multirow[t]{4}{*}{ Educational level } & No formal education & 6 & 3.1 \\
\hline & Grade 1-8 & 74 & 37.9 \\
\hline & Grade 9-12 & 69 & 35.4 \\
\hline & College and above & 46 & 23.6 \\
\hline \multirow[t]{5}{*}{ Occupation status } & Civil servants & 62 & 31.8 \\
\hline & Housewives & 39 & 20.0 \\
\hline & Non-governmental & 37 & 19.0 \\
\hline & Daily labor & 32 & 16.4 \\
\hline & Student & 25 & 12.8 \\
\hline \multirow[t]{4}{*}{ Living condition } & With family & 145 & 74.4 \\
\hline & Alone & 40 & 20.5 \\
\hline & With relatives & 10 & 5.1 \\
\hline & Merchant & 26 & 12.7 \\
\hline \multirow{3}{*}{$\begin{array}{l}\text { Average monthly } \\
\text { income }\end{array}$} & $<1647$ Ethiopian Birr & 111 & 56.9 \\
\hline & 1647-4537 Ethiopian Birr & 53 & 27.2 \\
\hline & > 4537 Ethiopian Birr & 31 & 15.9 \\
\hline
\end{tabular}

Brazil [30] and 27\% in USA [31]. On the other hand, the prevalence of AUD is lower than the studies in China which is $42.8 \%$ [11] and higher than the studies from Ethiopia which is $14.2 \%$ [23] and 14 in Nigeria [32]. The difference in prevalence of alcohol use disorder could be due to the variation in the study setting, data collection instrument and the cutoff point of the instrument which was used to assess alcohol use disorder and the sample size in the study. In addition, the disparities in the magnitude might be due to variations in the underlying social, cultural and economic status among the study countries.

Males were 2.43 times more likely to have AUD when compared to females. This is in agreement with studies 
Table 2 Clinical and psychosocial factors characteristics of the study participants, Hawassa, Ethiopia, 2019 ( $n=195)$

\begin{tabular}{|c|c|c|c|}
\hline Variables & Category & Frequency & Percent \% \\
\hline \multirow[t]{3}{*}{ Duration of the illness } & $<5$ years & 49 & 25.1 \\
\hline & $5-10$ years & 88 & 45.1 \\
\hline & $\geq 10$ years & 58 & 29.7 \\
\hline \multirow[t]{2}{*}{ CD4 count } & $<500$ & 114 & 58.5 \\
\hline & $\geq 500$ & 81 & 41.5 \\
\hline \multirow[t]{2}{*}{ Social support } & Good & 108 & 55.4 \\
\hline & Poor & 87 & 44.6 \\
\hline \multirow[t]{3}{*}{ Body mass index (BMI) Kg/M² } & $18.5-24.99$ & 134 & 68.7 \\
\hline & $25-29.99$ & 37 & 19.0 \\
\hline & $>30$ & 24 & 12.3 \\
\hline \multirow[t]{2}{*}{ Good medication adherence } & Yes & 170 & 87.2 \\
\hline & No & 25 & 12.8 \\
\hline \multirow[t]{2}{*}{ ART drug adherence } & Poor & 62 & 30.2 \\
\hline & Good & 143 & 69.8 \\
\hline \multirow[t]{2}{*}{ TB/HIV coinfection } & Yes & 48 & 24.6 \\
\hline & No & 147 & 75.4 \\
\hline \multirow[t]{2}{*}{ History of Hospital admission } & Yes & 61 & 31.3 \\
\hline & No & 134 & 68.7 \\
\hline \multirow[t]{2}{*}{ Past psychiatric history } & Yes & 16 & 8.2 \\
\hline & No & 179 & 91.8 \\
\hline \multirow[t]{2}{*}{ Family history of mental illness } & Yes & 12 & 6.2 \\
\hline & No & 183 & 93.8 \\
\hline \multirow[t]{2}{*}{ Past major surgery } & Yes & 26 & 13.3 \\
\hline & No & 169 & 86.7 \\
\hline \multirow[t]{2}{*}{ Current cigarette smoking } & Yes & 31 & 15.9 \\
\hline & No & 164 & 84.1 \\
\hline \multirow[t]{2}{*}{ Current chat (Khat) chewing } & Yes & 48 & 24.6 \\
\hline & No & 147 & 75.4 \\
\hline \multirow[t]{2}{*}{ Perceived stigma } & Yes & 58 & 29.7 \\
\hline & No & 137 & 70.3 \\
\hline
\end{tabular}

[9, 10, 23, 32]. Mostly, heavy drinking occurs among men when contrast to women and also biological differences among male and female could contribute to this difference [33].

AUD was more commonly seen among those individuals with poor social support. This is in-agreement to the other studies [9-11]. This could be due to the fact that getting minimal social support from their neighbors or any person might cause dissatisfaction in their life. As a result, they might use alcohol to get rid of their stress and dissatisfaction.

Poor medication adherence had a significant association with alcohol use disorder. Individuals with HIV who had poor medication adherence were 1.78 times
Table 3 Environmental and psychological factors associated with initiation of alcohol use disorders at Hawassa, Ethiopia, $2019(n=195)$

\begin{tabular}{lll}
\hline Reasons & Frequency & Percent \% \\
\hline Easily availability of alcohol & 32 & 16.4 \\
Like the way alcohol makes feel happy & 25 & 12.8 \\
Peer pressure to drink & 27 & 13.8 \\
Parental modeling & 16 & 8.2 \\
Long standing life stressors & 21 & 10.8 \\
Lack of social support & 23 & 11.8 \\
Long lasting marital disharmony & 13 & 6.7 \\
Drinking to forget financial problems & 15 & 7.7 \\
To increase self confidence & 14 & 7.2 \\
To alleviate fear of socializing & 10 & 5.1 \\
Family history of alcohol use problem & 18 & 9.2
\end{tabular}

more likely to have alcohol use disorder. None of the studies proved the relationship between alcohol and medication adherence. Alcohol intoxicated individuals might forget to take the medications due to their memory impairments as result of deficiency in vitamin B1 (Thiamine) due to alcohol drinking [34]. On the other hand, they might use alcohol as a coping strategy for their psycho-social stressors associated with illness.

Chewing khat and smoking cigarette had a statistically significant association with AUD. This is in line with other studies in Ethiopia $[9,23]$ and four African countries [10], USA [31] and China [11] respectively. This might be due to the fact that these substances are commonly interrelated with each other [34]. In addition to this, alcohol and cigarette (nicotine) could potentiate their rewarding effects and, cigarette smoking by itself bring down the intoxication and sedative effects of alcohol through stimulation [35].

\section{Conclusion}

In the current study, magnitude of alcohol use disorder among people living with HIV was high and calls for integrating services provided in HIV care and treatment clinic which enhances timely detection and management of AUD cases. Being male, having poor social support, current khat chewing, current cigarette smoking and poor medication adherence were statistically significant association with alcohol use disorder. This also alerts the stakeholders in HIV prevention and control programs to invest a greater efforts to retain patients in addiction treatment and rehabilitation centers. Lastly, appropriate screening and health education on consequences of alcohol use disorder is warranted. 
Table 4 Factors associated with alcohol use disorder among people living with HIV/AIDS at Hawassa, Ethiopia, 2019 ( $n=195)$

\begin{tabular}{|c|c|c|c|c|c|}
\hline \multirow[t]{2}{*}{ Characteristics } & & \multicolumn{2}{|c|}{$\underline{A \cup D}$} & \multirow{2}{*}{$\begin{array}{l}\text { Crude odds } \\
\text { ratio }(95 \% \mathrm{Cl})\end{array}$} & \multirow{2}{*}{$\begin{array}{l}\text { Adjusted odds } \\
\text { ratio }(95 \% \mathrm{Cl})\end{array}$} \\
\hline & & Yes & No & & \\
\hline \multirow[t]{2}{*}{ Gender } & Male & 42 & 45 & $4.11,(2.34,8.32)$ & $2.43,(1.76,5.76)^{* *}$ \\
\hline & Female & 20 & 88 & 1 & 1 \\
\hline \multirow[t]{2}{*}{ Social support } & Good & 27 & 81 & 1 & 1 \\
\hline & Poor & 35 & 52 & $2.01,(1.27,7.25)$ & $1.34,(1.12,6.73)^{*}$ \\
\hline \multirow[t]{2}{*}{ Good medication adherence } & Yes & 29 & 141 & 1 & 1 \\
\hline & No & 9 & 16 & $2.73,(1.95,8.87)$ & $1.78,(1.33,6.97)^{*}$ \\
\hline \multirow[t]{2}{*}{ Current chat (khat) chewing } & Yes & 28 & 20 & $2.21,(1.35,7.09)$ & $1.67,(1.16,5.45)^{* *}$ \\
\hline & No & 57 & 90 & 1 & 1 \\
\hline \multirow[t]{2}{*}{ Current cigarette smoking } & Yes & 21 & 10 & $6.30,(2.35,9.23)$ & $3.76,(2.16,7.54)^{* *}$ \\
\hline & No & 41 & 123 & 1 & 1 \\
\hline \multirow[t]{2}{*}{ HIV perceived stigma } & Yes & 40 & 18 & $3.31,(1.01,9.89)$ & $0.96,(0.87,5.12)$ \\
\hline & No & 55 & 82 & 1 & 1 \\
\hline \multirow[t]{3}{*}{ Body mass index (BMI) $\mathrm{Kg} / \mathrm{M}^{2}$} & $18.5-24.99$ & 32 & 102 & 1 & 1 \\
\hline & $25-29.99$ & 15 & 22 & $2.17,(1.22,6.38)$ & $0.77,(0.72,3.46)$ \\
\hline & $>30$ & 14 & 10 & $4.46,(2.32,7.75)$ & $0.93,(0.92,5.57)$ \\
\hline
\end{tabular}

Reference category $-1,{ }^{*}$ significant association ( $p$-value $\left.<0.05\right){ }^{* *}$ - significant association ( $p$-value $\left.<0.01\right)$

\section{Limitation of the study}

The study used standardized data collection instruments. However, some instruments are not validated to Ethiopian culture. This might over or under estimate the prevalence of AUD in this study. Because it was cross-sectional study design, it did not allow establishing a temporal relationship between AUD and other significantly associated factors.

\section{Abbreviations \\ AUD: Alcohol Use Disorder; AUDIT: Alcohol Used Disorders Identification Test; HAART: Highly Active Antiretroviral Therapy}

\section{Acknowledgements}

We would like to acknowledge Hawassa University, Ethiopia for funding the study. We also appreciate data collectors, supervisors and College of medicine and health sciences, Hawassa University Comprehensive specialized hospital for their help \& the study participants for their cooperation in providing all necessary information.

\section{Funding}

This study was funded by Hawassa University, Hawassa, Ethiopia.

\section{Availability of data and materials}

All relevant data are within the paper. If further data needed, it could be accessed from the main author upon request via email at berkole. dad@gmail.com.

\section{Authors' contributions}

$\mathrm{BD}$ conceived the study and was involved in the study design, reviewed the article, analysis, report writing and drafted the manuscript. AT was involved in the study design, proposal development and write up. YA was involved in reviewing articles. All authors read and approved the final manuscript.

\section{Ethics approval and consent to participate}

Ethical clearance for this study was obtained from the Research and Ethics Review Committee of the College of Medicine and Health Sciences, Hawassa University, Ethiopia. The letter from the research and community service directorate office was submitted to the ART clinic of the Hawassa University Comprehensive specialized hospital, Hawassa, Ethiopia. Study participants were informed about their rights to interrupt the interview at any time and written informed consent was obtained from each study participants. Name and other personal identifiers were not registered for the purpose of confidentiality. Confidentiality was maintained at all levels of the study.

\section{Consent for publication}

Not applicable.

\section{Competing interests}

The authors declare that they have no competing interests.

\section{Publisher's Note}

Springer Nature remains neutral with regard to jurisdictional claims in published maps and institutional affiliations.

\section{Author details}

${ }^{1}$ Faculty of Health Sciences, College of Medicine and Health Sciences, Hawassa University, P. O. Box 1560, Hawassa, Ethiopia. ${ }^{2}$ Faculty of Medical Sciences, College of Medicine and Health Sciences, Hawassa University, P. O. Box 1560, Hawassa, Ethiopia.

Received: 27 February 2019 Accepted: 9 May 2019

Published online: 20 May 2019

\section{References}

1. Akgun KM, Gordon K, Pisani M, Fried T, McGinnis KA, Tate JP, et al. Risk factors for hospitalization and medical intensive care unit (MICU) admission among HIV-infected veterans. Journal of acquired immune deficiency syndromes (1999). 2013;62(1):52-9.

2. Avalos LA, Mertens JR, Ward CL, Flisher AJ, Bresick GF, Weisner CM. Stress, substance use and sexual risk behaviors among primary care patients in Cape Town, South Africa. AIDS Behav. 2010;14(2):359-70.

3. Braithwaite RS, Conigliaro J, McGinnis KA, Maisto SA, Bryant K, Justice AC. Adjusting alcohol quantity for mean consumption and intoxication threshold improves prediction of nonadherence in HIV patients and HIVnegative controls. Alcohol Clin Exp Res. 2008;32(9):1645-51.

4. Baeza AG, Milinkovic A, Arenas-Pinto A. Low clinical relevance of risky alcohol consumption in a selected group of high adherent HIV-infected 
patients attended in the United Kingdom. J Int AIDS Soc. 2014;17(4 Suppl 3):19659.

5. Chaudhry AA, Sulkowski MS, Chander G, Moore RD. Hazardous drinking is associated with an elevated aspartate aminotransferase to platelet ratio index in an urban HIV-infected clinical cohort. HIV medicine. 2009;10(3):13342.

6. Conigliaro J, Gordon AJ, McGinnis KA, Rabeneck L, Justice AC. How harmful is hazardous alcohol use and abuse in HIV infection: do health care providers know who is at risk? Journal of acquired immune deficiency syndromes (1999). 2003;33(4):521-5.

7. WHO. Prevention of psychoactive substance use: a selected review of what works in the area of prevention. 2002. https://www.who.int/substance_ abuse/publications/en/prevention_substance_use.pdf.

8. Fekadu A, Alem A, Hanlon C. Alcohol and drug abuse in Ethiopia: past,present and future. African journal of drug and alcohol studies. 2007; 6(1).

9. Soboka M, Tesfaye M, Tolu G, Hanlon C. Alcohol use disorders and associated factors among people living with HIV who are attending services in south west. Ethiopia BMC Research Notes. 2014;7(1):828-1-828-8.

10. Nouaman MN, Vinikoor M, Seydi M, Ekouevi DK, Coffie PA, Mulenga $L$, et al. High prevalence of binge drinking among people living with HIV in four African countries. J Int AIDS Soc. 2018;21(12):e25202.

11. Pokhrel KN, Gaulee Pokhrel K, Neupane SR, Sharma VD. Harmful alcohol drinking among HIV-positive people in Nepal: an overlooked threat to antiretroviral therapy adherence and health-related quality of life. Glob Health Action. 2018;11(1):1441783.

12. Goar SG, Audu MD, Agbir MT, Dochalson E. Prevalence and sociodemographic correlates of alcohol use disorders among HIV patients. African Journal of Drug \& Alcohol Studies. 2011;(1):10.

13. Parsons JT, Starks TJ, Millar BM, Boonrai K, Marcotte D. Patterns of substance use among HIV-positive adults over 50: implications for treatment and medication adherence. Drug Alcohol Depend. 2014;139:33-40.

14. Cerutti B, Broers B, Masetsibi M, Faturiyele O, Toti-Mokoteli L, Motlatsi M, et al. Alcohol use and depression: link with adherence and viral suppression in adult patients on antiretroviral therapy in rural Lesotho, southern Africa: a cross-sectional study. BMC Public Health. 2016;16:947.

15. Chander G, Josephs J, Fleishman JA, Korthuis PT, Gaist P, Hellinger J, et al. Alcohol use among HIV-infected persons in care: results of a multi-site survey. HIV medicine. 2008;9(4):196-202.

16. Silverberg MJ, Leyden WA, Leibowitz A, Hare CB, Jang HJ, Sterling $\mathrm{S}$, et al. Factors associated with hazardous alcohol use and motivation to reduce drinking among HIV primary care patients: baseline findings from the Health \& Motivation study. Addict Behav. 2018;84:110-7.

17. Veld DHI, Pengpid S, Colebunders R, Skaal L, Peltzer K. High-risk alcohol use and associated socio-demographic, health and psychosocial factors in patients with HIV infection in three primary health care clinics in South Africa. Int J STD AIDS. 2017;28(7):651-9.

18. Wardell JD, Shuper PA, Rourke SB, Hendershot CS. Stigma, coping, and alcohol use severity among people living with HIV: a prospective analysis of bidirectional and mediated associations. Annals of behavioral medicine: a publication of the Society of Behavioral Medicine. 2018;52(9):762-72.

19. Cox J, Maurais E, Hu L, Moodie EE, Law S, Bozinoff N, et al. Correlates of drug use cessation among participants in the Canadian HIV-HCV coinfection cohort. Drug Alcohol Depend. 2014;137:121-8.

20. Peltzer K. Longitudinal analysis of HIV risk behaviour patterns and thei predictors among public primary care patients with tuberculosis in South Africa. SAHARA J : journal of Social Aspects of HIV/AIDS Research Alliance. 2018;15(1):1-6.

21. Gonzalez-Alvarez S, Madoz-Gurpide A, Parro-Torres C, Hernandez-Huerta D, Ochoa Mangado E. Relationship between alcohol consumption, whether linked to other substance use or not, and antiretroviral treatment adherence in HIV+ patients. J Viral Hepat. 2017;0(0):916.

22. Myers B, Sorsdahl K, Morojele NK, Kekwaletswe C, Shuper PA, Parry CD. "in this thing I have everything I need": perceived acceptability of a brief alcohol-focused intervention for people living with HIV. AIDS Care. 2017; 29(2):209-13.

23. Bultum JA, Yigzaw N, Demeke W, Alemayehu M. Alcohol use disorder and associated factors among human immunodeficiency virus infected patients attending antiretroviral therapy clinic at Bishoftu GeneralHospital, Oromiya region, Ethiopia. PLoS One. 2018;13(3):e0189312.
24. Reinert DF, Allen JP. The alcohol use disorders identification test (AUDIT): a review of recent research. Alcohol Clin Exp Res. 2002;26(2):272-9.

25. Van Rie A, Sengupta S, Pungrassami P, Balthip Q, Choonuan S, Kasetjaroen $Y$, et al. Measuring stigma associated with tuberculosis and HIV/AIDS in southern Thailand: exploratory and confirmatory factor analyses of two new scales. Tropical Med Int Health. 2008;13(1):21-30.

26. Franke MF, Muñoz M, Finnegan K, Zeladita J, Sebastian $J L$, Bayona JN, Shin SS. Validation and abbreviation of an HIV stigma scale in an adult Spanishspeaking population in urban Peru. Aids \& Behavior. 2010;14:189-99.

27. Tan X, Patel I, Chang J. Review of the four item Morisky medication adherence scale (MMAS-4) and eight item Morisky medication adherence scale (MMAS-8). University of Minnesota, College of Pharmacy Retrieved from the University of Minnesota Digital Conservancy. 2014; https:// conservancy.umn.edu/handle/11299/171823.

28. Dalgard OS, Dowrick C, Lehtinen V, Vazquez-Barquero JL, Casey P, Wilkinson $G$, et al. Negative life events, social support and gender difference in depression. Soc Psychiatry Psychiatr Epidemiol. 2006;41(6):444-51.

29. da Silva CM, Mendoza-Sassi RA, da Mota LD, Nader MM, de Martinez AM. Alcohol use disorders among people living with HIV/AIDS in southern Brazil: prevalence, risk factors and biological markers outcomes. BMC Infect Dis. 2017;17(1):263. https://doi.org/10.1186/s12879-017-2374-0.

30. Crane HM, McCaul ME, Chander G, Hutton H, Nance RM, Delaney J, et al. Prevalence and factors associated with hazardous alcohol use among persons living with HIV across the US in the current era of antiretroviral treatment. AIDS Behav. 2017;21(7):1914-25.

31. Wang Y, Chen X, Ball J, Li X, Zhou Y, Shen Z. Self-reported changes in alcohol use behavior among people living with HIV in China after receiving HIV positive diagnosis. SAGE open medicine. 2018;6:2050312118755783.

32. Egbe CO, Dakum PS, Ekong E, Kohrt BA, Minto JG, Ticao CJ. Depression, Suicidality, and alcohol use disorder among people living with HIV/AIDS in Nigeria. BMC Public Health. 2017;17(1):542

33. Wilsnack RW, Vogeltanz ND, Wilsnack SC, Harris TR, et al. Gender differences in alcohol consumption and adverse drinking consequences: cross-cultural patterns. Addiction. 2000;95:251-65.

34. Amberbir A, Woldemicheal K, Getachew S, Girma B, Deribe K. Predictors of adeherance to ART therapy among HIV infected persons: a prospective study in Southwest Ethiopia. BMC Public Health. 2008:8:265.

35. Adams S. Psychopharmacology of tobacco and alcohol comorbidity: a review of current evidence. Current addiction reports. 2017:4(1):25-34.

\section{Ready to submit your research? Choose BMC and benefit from:}

- fast, convenient online submission

- thorough peer review by experienced researchers in your field

- rapid publication on acceptance

- support for research data, including large and complex data types

- gold Open Access which fosters wider collaboration and increased citations

- maximum visibility for your research: over $100 \mathrm{M}$ website views per year

At $\mathrm{BMC}$, research is always in progress.

Learn more biomedcentral.com/submission 